\title{
Mini Review: Is fluoroquinolone drug or poison?
}

\author{
Fatima Zohra Mimouni' ${ }^{1}$, Nasser Belboukhari' ${ }^{2}$, Khaled Sekkoum ${ }^{3}$ \\ ${ }_{1,2,3}$ Bioactive Molecules and Chiral Separation Laboratory, Tahri Mohamed University, Bechar, Algeria \\ ${ }^{1}$ Department of Chemistry, Kasdi Merbah University, Ouargla, Algeria \\ ${ }^{1}$ Corresponding author \\ E-mail: ${ }^{1}$ mimouni2401@yahoo.fr, ${ }^{2}$ belboukhari.nasser@yahoo.com, ${ }^{3}$ khalidos669@yahoo.fr
}

Received 15 August 2019; received in revised form 10 October 2019; accepted 18 October 2019 DOI https://doi.org/10.21595/chs.2019.20952

Check for updates

Copyright (C) 2019 Fatima Zohra Mimouni, et al. This is an open access article distributed under the Creative Commons Attribution License, which permits unrestricted use, distribution, and reproduction in any medium, provided the original work is properly cited.

\begin{abstract}
Quinolones are a class of broad-spectrum antibiotics with valuable pharmacological properties due to their improved pharmacokinetic properties, particular mechanism of action and broad and potent activity; being one of the fastest growing class antibacterial growths in terms of therapeutic use and overall benefit. Because of their effectiveness, spectrum of activity, and generally good safety profile, fluoroquinolones were used widely for multiple clinical indications throughout the world. Although still clinically valuable, fluoroquinolone use has become limited in some clinical situations, as bacterial resistance has emerged over time. In the sections that follow we review the range of molecular mechanisms that motivate quinolone resistance.
\end{abstract}

Keywords: quinolones, antimicrobial resistance, mechanism of action, DNA gyrase, topoisomerase IV.

\section{Introduction}

The Quinolones are the first synthetic antibacterial agents used in humans, they are bactericidal, they form a class of antibiotics that has taken an important place in the arsenal therapeutic. Quinolones owe their discovery to chloroquine research. Laboratory researchers Sterling-Winthrop (Rochester, NY) accidentally discovered a product derived from its synthesis and endowed with antibacterial properties: 7-chloroquinoline. This molecule has been developed to give nalidixic acid (Fig. 1). Currently, more than 10.000 base core derivatives have been described $[1,2]$.<smiles>CCCCCn1cc(C(=O)O)c(=O)c2ccc(Cl)cc21</smiles>

Fig. 1. From chloroquine to nalidixic acid

The Quinolones are synthetic antibacterial agents comprising two fused aromatic rings, a pyridine ring with a 4-ketone function, a 3-carbon carboxylic acid, 1-substituted nitrogen, and the second is a heterocycle (pyridine or pyrimidine) or a benzene [3].

\section{Quinolones classification}

The classification of fluoroquinolones takes into account the antimicrobial spectrum and their clinical indications. This classification is a tool for doctors to use when prescribing these drugs or evaluating new active ingredients introduced into the market. One drug in each group is similar to 
an antimicrobial activity. With each successive generation, a large new group of pathogens is added to the cover. Quinolones are usually classified into four generations based on their activity and spectrum of activity [4].<smiles>[R6]c1[Y]c2c(c([R5])c1[R])c(=O)c(C(=O)O)cn2[Z1]</smiles>

Fig. 2. Common structure of quinolones

\subsection{First generation}

In 1962, Lesher G. Y. and his collaborators presented the primary derivative of quinolone, nalidixic acid, which has direct action against Gram-negative bacteria and has been utilized to treat urinary tract diseases. Within the taking after a long time, a wide extend of products derived from common components were synthesized, which might be gathered by: cinoline (cinoxacin), pyrido-pyrimidine (pipemidic acid, piromidic acid), naphthyridine (nalidixic corrosive) and quinolones (oxolinic acid, miloxacin, tioxacin, etc.). These derivatives, with separated structures, have two common pharmacological properties:

- A fine antibacterial range, extraordinarily planned for Enterobacteriaceae;

- A pharmacokinetics that permits quick disposal and diminished tissue intrigued, as it were permitting them to be utilized as urinary cleaning agents [5].<smiles>CCCCCCn1cc(C(=O)O)c(=O)c2ccc(C)nc21</smiles>

Nalidixic acid<smiles>CCCCCCCn1nc(C(=O)O)c(=O)c2cc3c(cc21)OCO3</smiles>

Cinoxacin<smiles>CCCCCCCCn1cc(C(=O)O)c(=O)c2cc3c(cc21)OCO3</smiles>

Oxolinic acid<smiles>CCCCCn1cc(C(=O)O)c(=O)c2cnc(N3CCCC3)nc21</smiles>

Miloxacin

Piromidic acid

Pipemidic acid

Fig. 3. Quinolones of first generation

The victory of early era quinolones fortified inquire about in this zone, which driven to the blend getting, after 1980, of a unused series of compounds with solid antibacterial properties and a large range of antibacterial movement that included Gram-positive and Gram negative. 


\subsection{Second generation}

Koga and his collaborators presented Norfloxacin in clinical utilize in 1980, the primary quinolone with a fluorine atom substituted within the C-6 position and a C-7 piperazine. Norfloxacin was the primary quinolone with expanded antimicrobial action, acting on a wide range of Gram-positive and Gram-negative microscopic organisms, counting Pseudomonas aeruginosa microorganisms [6].<smiles>CCCCCCCCn1cc(C(C)=O)c(=O)c2cc(F)c(N3CCNCC3)cc21</smiles><smiles>CCn1cc(C(N)=O)c(=O)c2cc(F)c(N3CCN(C)CC3)cc21</smiles><smiles>CC(=O)c1cn(C2CC2)c2cc(N3CCNCC3)c(F)cc2c1=O</smiles><smiles>CCn1cc(C(=O)O)c(=O)c2cc(F)c(N3CCN(C)CC3)c(F)c21</smiles>
Fleroxacin

<smiles>CN1CCN(c2cc3c(cc2F)c(=O)c(C(=O)O)cn3N)CC1</smiles><smiles>CCCCCn1cc(OC)c(=O)c2cc(F)c(N3CCNCC3)nc21</smiles>

Enoxacin<smiles>CC1COc2c(N3CCN(C)CC3)c(F)cc3c(=O)c(OC(N)=O)cn1c23</smiles>

Ofloxacin<smiles>CCCCCCCCCCC(=O)c1cn2c3c(c(N4CCN(C)CC4)c(F)cc3c1=O)SCC2</smiles>

Rufloxacin

Fig. 4. Quinolones of second generation

Investigate within the field of derivatives with a quinolone structure has driven to modern compounds gotten, which have been classified as third and fourth era systemic quinolones, generally compelling against Staphylococcus aureus. Their wide antibacterial range incorporates anaerobes, Chlamydia and Mycoplasma [7].

\subsection{Third generation}

Third-generation agents currently include levofloxacin, grepafloxacin, and sparfloxacin. These agents are separated into a third class because of their expanded action against gram-positive organisms, counting the penicillin-resistant Streptococcus pneumoniae [8].

\subsection{Fourth generation}

The fourth generation has the taking after common angles: an indistinguishable instrument of activity by the restraint of DNA gyrase A subunit, solely chromosomal resistance of microbes and certain impacts of comparative microbes: photo-toxicity, neurotoxicity, cartilage harmfulness [9].

So far, a huge number of antibacterial substances having a place to the class said over has been utilized in medication. Quinolones are utilized when treating urinary tract diseases, respiratory tract, intestinal contaminations, ear/nose/throat infections, tissue contaminations and mellow skin, meningitis caused by gram-negative microbes and Staphilococci microscopic organisms, 
infections of the liver and bile channels, sepsis and endocarditis, prophylaxis and surgical diseases and on patients with safe lack.<smiles>CNC1CCCN(c2c(F)cc3c(=O)c(C(N)O)cn(C4CC4)c3c2C)C1</smiles>

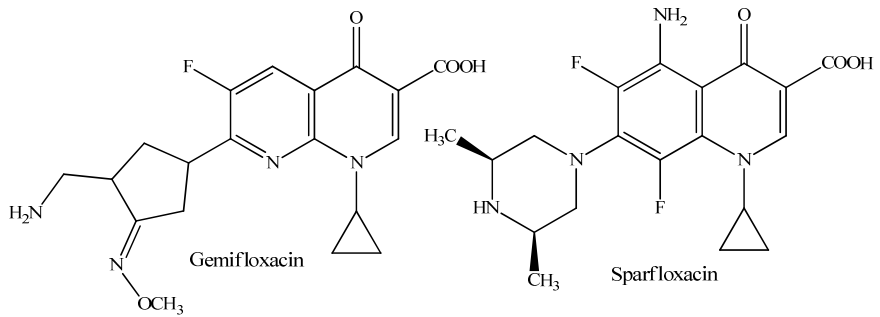<smiles>C[C@@H]1COc2c(N3CCN(C)CC3)c(F)cc3c(=O)c(C(N)=O)cn1c23</smiles><smiles>C[C@@H]1COc2c(C3(N)CC3)c(F)cc3c(=O)c(C(N)=O)cn1c23</smiles>

Pazufloxacin<smiles>CC1CN(c2cc3c(cc2F)c(=O)c(C(=O)O)cn3-c2ccc(F)cc2F)CCN1</smiles><smiles>NC(=O)c1cn(-c2ccc(F)cc2F)c2nc(N3CCC(N)C3)c(F)cc2c1=O</smiles>

Fig. 5. Quinolones of third generation



Fig. 6. Quinolones of fourth generation 


\section{Mechanism of action and resistance}

\subsection{Intra-bacterial penetration}

Gram (+) bacteria lack an outer membrane, with a wall consisting of a thick peptidoglycan. The penetration of quinolones is by passive diffusion.

For bacteria with gram $(-)$, the intrabacterial penetration is done by two ways:

- The porin pathway: hydrophilic channels in the form of trimers for hydrophilic and small quinolones $(<400$ dalton) (norfloxacin and ciprofloxacin).

- The lipopolysaccharide (LPS) pathway: by $\mathrm{Mg} 2+$ chelation associated with LPS and discovery of hydrophobic zones, hence the penetration of hydrophobic quinolones (sparfloxacin) [10].

\subsection{Mechanisms of quinolone action}

QNs interfere with changes in DNA supercoiling by binding to II or IV. This leads to the formation of double-stranded DNA breaks and cell death either in a protein synthesis dependent manner or in a manner independent of protein synthesis [11]. They target two parent enzymes belonging to the family of topoisomerases II and which are involved in the synthesis of bacterial DNA: DNA-gyrase (generally the main target in Gram-negative bacteria) and topoisomerase IV (usually the main target in Gram-positive bacteria).

New fluoroquinolones such as gatifloxacin and moxifloxacin have both activities. DNA Gyrase is composed of two GyrA subunits encoded by the gyrA gene and two GyrB subunits encoded by the gyrB gene. It introduces a negative supercoiling into the bacterial DNA double helix upstream of the replication fork. This activity is essential for the initiation of bacterial DNA replication and for transcription $[12,13]$.

Topoisomerase IV has a decatenation activity that allows the separation of replicated chromosomes at the end of a replication sequence. It is composed of 4 subunits homologous to those of gyrase, two ParC subunits (homologues of GyrA) and two ParE subunits (homologues of GyrB) encoded by the genes parC and parE respectively [14].

\subsection{Mechanisms of quinolone resistance}

As for many antibiotics, the resistance goes through two main mechanisms: reduction of the intrabacterial concentration of the antibiotic and alteration of its target enzymes. For the latter mechanism, it is in fact mutations in genes encoding DNA gyrase and topoisomerase IV. This type of mutation is stable and spread easily in the bacterial environment. The clinical resistance appears according to a mechanism in step of staircase by accumulation of several genetic mutations. This can induce class resistance to all quinolones, or only certain family molecules.

Here again, the presence of a methoxy group in the 8-position, as for moxifloxacin and gatifloxacin, is important since it reduces the probability of selection of mutant resistant [15-18]. As for reducing the concentration of antibiotics in the bacteria, it can involve several mechanisms, including changes in the external bacterial membrane, such as the modification of protein structures called porins, which provide a part of the exchanges between the outside and the outside. inside the bacteria. Since these exchange systems are not specific for the molecules transported, the acquisition of this type of resistance can also lead to a reduction in sensitivity to other classes of antibiotics, notably carbapenems [15].

The reduction of the concentration of quinolones in the bacterium can also be the consequence of the increase in its output, by a so-called efflux system. This mechanism can either make the bacterium resistant to the antibiotic itself if it is very powerful, or allow the bacterium to survive in a suboptimal concentration of antibiotics, which ultimately promotes the appearance of genetic mutations in the body. made of a major pressure of antibiotic selection then playing at its 
maximum efficiency. It is therefore in all cases a mechanism promoting resistance to quinolones, and its low specificity tends to allow the emergence of multiresistance.

Finally, quinolone resistance can also be transmitted by plasmids. However, this phenomenon well described in Klebsiella sp. and Escherichia coli appear to be rare for other bacterial families, except in certain geographic areas such as East Asia [19].

\section{Fluoroquinolones toxicity}

For decades, administrative organizations and the therapeutic calling were doubtful that a brief course of anti-microbials might have such an obliterating, long-term affect. But after diligent campaigning by quiet bunches, states of mind started to alter in 2008, when the FDA declared the primary of what would be an arrangement of solid alarms around the side impacts of fluoroquinolone drugs, counting ligament crack and irreversible nerve harm [20]. In 2016, the organization acknowledged the presence of a possibly changeless disorder, and prescribed that the drugs be saved for genuine diseases [21].

Fluoroquinolones are important anti-microbials, and secure for most individuals. However, they are so broadly endorsed that their side impacts might have hurt hundreds of thousands of individuals say researchers who are working with patients [21]. Fluoroquinolone harmfulness gives a compelling illustration of a rising understanding that anti-microbials don't fair hurt organisms but they can extremely harm human cells as well [23].

\section{Conclusions}

Fluoroquinolone resistance isn't straightforward and our understanding of the numerous components of resistance, the biological effect of each on the have strain, and the transaction between diverse instruments has expanded drastically in later a long time. Additionally, the longterm destiny of distinctive strains of distinctive species with differing combinations of fluoroquinolone-resistance changes is greatly difficult to predict. Clearly there's no 'one-size-fitsall' reply to how fluoroquinolone resistance will influence the advancement of pathogens and wide conclusions based on one life form may not be significant to all. What is getting to be progressively clear is that resistance to fluoroquinolones can be chosen beneath a wide extend of particular conditions and in certain circumstances safe strains may illustrate a fitness advantage over antibiotic-sensitive strains, indeed within the nonappearance of fluoroquinolone pressure.

Fluoroquinolone resistance is common and typically likely to be related to the science of resistance as well as a coordinate reaction to medicate weight. Subsequently, minimizing resistance will not be as straightforward as confining the utilize of these agents.

However, this antibiotic linked to toxicity that's left many chronically ill, should be used as last resort only.

\section{References}

[1] Appelbaum P. C., Hunter P. A. The fluoroquinolone antibacterial: past, present and future perspectives. International Journal of Antimicrobial Agents, Vol. 16, Issue 1, 2000, p. 5-15.

[2] Sàrközy G. Quinolones: A Class of Antimicrobial Agents. Veterinární Medicína, Vol. 46, Issue 9, 2001, p. 257-274.

[3] Thomas J. New quinolones and the impact on resistance. Drug Discovery Today, Vol. 6, Issue 10, 2001, p. 529-536.

[4] Gillespie S. H., Kennedy N. The fluoroquinolones: a new treatment for tuberculosis? The International Journal of Tuberculosis and Lung Disease, Vol. 2, Issue 4, 1998, p. 265-271.

[5] Leshe G. Y., Foelich E. J., Garnett M. D., Bayley J. H., Brundage P. R. 1,8 naphtyridine derivatives, a new class of chemotherapeutic agents. Journal of Medicinal Chemistry, Vol. 5, Issue 5, 1962, p. 259-279. 
[6] Koga H., Itoh A., Murayama S. Structure-activity relationships of antibacterial 6,7- and 7,8Disubstituted 1-alkyl-1,4-dihydro-4-oxoquinoline-3-carboxylic acids. Journal of Medicinal Chemistry, Vol. 23, Issue 12, 1980, p. 1358-1363.

[7] Brighty K., Gootz T. Chemistry and Mechanism of Action of the Quinolone Antibacterial, in: the Quinolones. 3rd Edition, Vincent Andriole Academic Press, London, 2000, p. 33-97.

[8] Khan A. U. Current Trends in Antibiotic Resistance in Infectious Diseases. I. K. International Pub House, New Delhi, 2009, p. 114-115.

[9] Bartlett J. D., Jaanus S. D. Anti-infective Drugs: Clinical Ocular Pharmacology. 5th Edition, Elsevier Health Sciences, Canada, 2008, p. 195-197.

[10] Drlica K. Mechanism of fluoroquinolone action. Current Opinion in Microbiology, Vol. 2, Issue 1, 1999, p. 504-508.

[11] Espeli O., Marians K. J. Untangling intracellular DNA topology. Molecular Microbiology, Vol. 52, Issue 1, 2004, p. 925-931.

[12] Hooper D. C. Mechanisms of drug resistance: quinolone resistance. Annual New York Academic Sciences, Vol. 1354, Issue 1, 2015, p. 12-31.

[13] Levine C., Hiasa H., Marians K. J. DNA gyrase and topoisomerase IV: biochemical activities, physiological roles during chromosome replication, and drug sensitivities. Biochimica Biophysica Acta, Vol. 1400, Issues 1-3, 1998, p. 29-43.

[14] Zechiedrich E. L., Khodursky A. B., Cozzarelli N. R. Topoisomerase IV, not gyrase, decatenates products of site-specific recombination in Escherichia coli. Genes and Development, Vol. 11, Issue 19, 1997, p. 2580-2592.

[15] Van Bambeke F., Michot J. M., Van Eldere J., Tulkens P. M. Quinolones in 2005: an update. Clinical Microbiology and Infection, Vol. 11, Issue 4, 2005, p. 256-280.

[16] Dong Y., Xu C., Zhao X., Domagala J., Drlica K. Fluoroquinolone action against mycobacteria: effects of c-8 substituents on growth, survival, and resistance. Antimicrobial Agents Chemotherapy, Vol. 42, Issue 11, 1998, p. 2978-2984.

[17] Dalhoff A. Comparative in vitro and in vivo activity of the C-8 methoxy quinolone moxifloxacin and the C-8 chlorine quinolone BAY y 3118. Clinical Infectious Diseases, Vol. 32, 2001, p. 16-22.

[18] Zhao X., Xu C., Domagala J., Drlica K. DNA topoisomerase targets of the fluoroquinolones: a strategy for avoiding bacterial resistance. Proceedings of National Academy of Sciences, Vol. 94, Issue 25, 1997, p. 13991-13996.

[19] Hooper D. C., Rubinstein E. Quinolone Antimicrobial Agents. 3rd Edition. ASM Press, Washington DC, 2003, p. 41-67.

[20] Tennyson L. E., Averch T. D. An update on fluoroquinolones: the emergence of a multisystem toxicity syndrome. Urology Practice, Vol. 4, Issue 5, 2017, p. 383-387.

[21] Gao Z., Chen Y., Guan M. X. Mitochondrial DNA mutations associated with aminoglycoside induced ototoxicity. Journal of Otology, Vol. 12, Issue 1, 2017, p. 1-8.

[22] Kalghatgi S., et al. Bactericidal antibiotics induce mitochondrial dysfunction and oxidative damage in mammalian cells. Science Translational Medicine, Vol. 5, Issue 192, 2013, p. 192 ra85.

[23] Badal S., Her Y. F., Maher Iii L. J. Nonantibiotic effects of fluoroquinolones in mammalian cells. Journal of Biological Chemistry, Vol. 290, Issue 36, 2015, p. 22287-22297. 